\title{
Follicle and corpus luteum size and vascularity as predictors of fertility at the time of artificial insemination and embryo transfer in beef cattle ${ }^{1}$
}

\author{
Fábio L.V. Pinaffi² ${ }^{2 *}$ Ériko S. Santos², Maurício G. da Silva², Milton Maturana Filho ${ }^{3}$, \\ Ed H. Madureira ${ }^{3}$ and Luciano A. Silva ${ }^{2}$
}

\begin{abstract}
Pinaffi F.L.V., Santos E.S., Silva M.G., Maturana Filho M., Madureira E.H. \& Silva L.A. 2015. Follicle and corpus luteum size and vascularity as predictors of fertility at the time of artificial insemination and embryo transfer in beef cattle. Pesquisa Veterinária Brasileira 35(5):470-476. Laboratório de Teriogenologia, Departamento de Medicina Veterinária, Faculdade de Zootecnia e Engenharia de Alimentos, Universidade de São Paulo, Av. Duque de Caxias Norte 225, Pirassununga, SP 13635-900, Brazil. E-mail: fabio_pinaffi@hotmail.com

Two ultrasound based fertility prediction methods were tested prior to embryo transfer (ET) and artificial insemination (AI) in cattle. Female bovines were submitted to estrous synchronization prior to ET and AI. Animals were scanned immediately before ET and AI procedure to target follicle and corpus luteum (CL) size and vascularity. In addition, inseminated animals were also scanned eleven days after insemination to target CL size and vascularity. All data was compared with fertility by using gestational diagnosis 35 days after ovulation. Prior to ET, CL vascularity showed a positive correlation with fertility, and no pregnancy occurred in animals with less than $40 \%$ of CL vascularity. Prior to AI and also eleven days after AI, no relationship with fertility was seen in all parameters analyzed (follicle and CL size and vascularity), and contrary, cows with CL vascularity greater than $70 \%$ exhibit lower fertility. In inseminated animals, follicle size and vascularity was positive related with CL size and vascularity, as shown by the presence of greater CL size and vascularity originated from follicle with also greater size and vascularity. This is the first time that ultrasound based fertility prediction methods were tested prior to ET and AI and showed an application in ET, but not in AI programs. Further studies are needed including hormone profile evaluation to improve conclusion.
\end{abstract}

INDEX TERMS: Fertility, follicle, corpus luteum, ultrasound, color-Doppler, cattle.

RESUMO.- [Tamanho e vascularização do folículo e corpo lúteo como preditores de fertilidade após inseminação artificial e transferência de embriões em gado de corte.] Duas técnicas de predição de fertilidade, baseadas em ultrassonografia, foram testadas no momento da transferência de embriões (TE) e inseminação artificial (IA) em bovinos. Fêmeas bovinas foram submetidas a protocolos de sincroniza-

\footnotetext{
${ }^{1}$ Received on July 23, 2014.

Accepted for publication on December 13, 2014.

2 Laboratório de Teriogenologia Dr. O.J. Ginther, Departamento de Medicina Veterinária, Faculdade de Zootecnia e Engenharia de Alimentos (FZEA), Universidade de São Paulo (USP), Av. Duque de Caxias Norte 225, Jardim Elite, Pirassununga, SP 13635-900, Brazil. *Corresponding author: fabio_pinaffi@hotmail.com

${ }^{3}$ Departamento de Reprodução Animal, FMVZ-USP, Av. Duque de Caxias Norte 225, Jardim Elite, Pirassununga, SP 13635-900.
}

ção de estro para TE e IA. Os animais foram escaneados por ultrassonografia imediatamente antes do procedimento de TE e IA para identificar o tamanho e vascularização do folículo e corpo lúteo (CL). Além disso, os animais inseminados foram escaneados onze dias após a inseminação para identificar o tamanho e vascularização do CL. Todos os dados foram comparados com a fertilidade utilizando-se do diagnóstico gestacional 35 dias após a ovulação. No momento da TE, a vascularização do CL apresentou-se positivamente relacionada com a fertilidade, sendo que animais com menos de $40 \%$ de vascularização do CL não ficaram gestantes. No momento da IA, assim como onze dias após a IA, nenhuma relação foi encontrada entre fertilidade e os parâmetros analizados (tamanho e vascularização do folículo e CL), enquanto que contrariamente, houve uma queda na fertilidade em vacas com vascularização do CL acima de 70\%. Nos animais insemina- 
dos, o tamanho e vascularização do folículo foi positivamente relacionado ao tamanho e vascularização do CL, demonstrado pela presença de um CL maior e mais vascularizado proveniente de um folículo maior e mais vascularizado. 0 presente estudo é o primeiro a mostrar métodos de predição de fertilidade baseados em ultrassonografia no momento da IA e TE, demonstrando uma aplicabilidade prática no momento da TE. Novos estudos são necessários para suportar os resultados mostrados, incluindo análises hormonais.

TERMOS DE INDEXAÇÃO: Fertilidade, folículo, corpo lúteo, ultrassonografia, Doppler colorido, bovino.

\section{INTRODUCTION}

Assisted reproduction techniques (ART) are highly diffused in cattle industry, aiming to increase herd fertility as well synchronize births and homogenate the herd age for slaughter. Artificial insemination (AI) and embryo transfer (ET) can be defined as the major ART techniques in cattle industry. These two ART techniques are efficient and with suitable results for cattle production, although a "fine tuning" is necessary to achieve even greater reproductive results.

New studies aimed to increase herd fertility index by hormone treatments (Bisinotto et al. 2011) or improving semen quality (Kastelic et al. 2008). However, the evaluation of the success of each new approach used to increase herd fertility is, in practice, only measured by gestational diagnosis 35 days after ovulation. Earlier pregnancy detection is not been used yet, although was already tested (Siqueira et al. 2013), mainly by transrectal ultrasonography. Early gestational diagnosis had aimed to improve herd production, since it could enable an early reintroduction of the non-pregnant cows in reproduction, and an increased number of pregnant animals in a shorter time. In addition, real time methods to predict fertility at the time of AI and ET procedure were also previously tested (Silva et al. 2006, Siddiqui et al. 2008, Sá Filho et al. 2010a). Therefore, an immediate diagnosis to help the decision of using or discarding an animal from an AI or ET program is still questionable.

Follicle vascularity and its effects on fertility had been investigated in mares (Silva et al. 2006) and cows (Shrestha et al. 2006, Siddiqui et al. 2008). Near ovulation, was shown that an extensive vascularity is formed in the follicular wall until the ovulation occurs (Geva \& Jaffe 2000, Reisinger et al. 2007). Subjective and objective methods are validated and can be used to measure follicular vascularity in cows and mares (Ginther et al. 2007). Previous works showed that follicles with greater diameter resulted in also greater pregnancy rates (Sá Filho et al. 2010a). Furthermore, preovulatory follicles with greater size originated CLs with greater size and presenting higher production of progesterone (Bisinotto et al. 2012, Machado et al. 2008).

Several studies addressed the role of the vascularity of genital organs in the estrous cycle, reproductive life, and gestation (Reed et al. 1996, Nautrup 1998, Bollwein et al. 2000, 2002a, 2002b, 2004, Köster et al. 2001, Alvarez-Clau \& Liste 2005, Di Salvo et al. 2006, Scotti et al. 2008, Brito et al. 2010, Miranda \& Domingues 2010, Polisca et al. 2010, Blanco et al. 2011, Pereira et al. 2012a, 2012b). Color-Doppler ultrasonography was previously used in cows to evalu- ate the vascularity of follicle, CL, and conceptus (Myamoto et al. 2005, 2006, Pareja et al. 2010, Silva et al. 2010). Therefore, since it is a non invasive technique and with reliable application, it is a useful tool to target new reproductive diagnoses. The evaluation of perifollicular vascularity was done in cows (Siddiqui et al. 2008), women (Coulam et al. 1999, Bhal et al. 2001, Borini et al. 2001), and mares (Silva et al. 2006), and in all of these species was detected greater vascularity in the preovulatory follicle wall in individuals that became pregnant after mating.

Ultrasonography in B- and color-Doppler modes of the CL can potentially be used as a diagnosis tool to select better recipients for an ET program, as well to early detect gestational losses. Previously, it was noted that pregnancy rate was not correlated with CL diameter (Nunes et al. 2011), although greater CL area was positive correlated with pregnancy (Baruselli et al. 2003, Nunes et al. 2011). Measurement of CL vascularity was suggested as a diagnosis technique for early pregnancy, but the early detection of pregnancy by evaluation of CL vascularity did not appeared to be a specific and sensitive method (Utt et al. 2009). The physiologic aspects of CL vascularity by ultrasonography during formation and lysis were previously described in cows (Acosta et al. 2003, Acosta \& Miyamoto 2004, Miyamoto et al. 2005, Ginther et al. 2007), using objective and subjective analyses (Ginther et al. 2007). The corpus luteum vascularity is immediately constituted after ovulation (Reynolds et al. 2000), and CL vascularity is associated with its functionality (Bollwein et al. 2002b). CL size and vascularity is positively correlated with progesterone production, and appeared to be a suitable predictor of progesterone secretion (Acosta et al. 2003, Mann 2009). In addition, the evaluation of CL vascularity should be a useful method to evaluate conceptus development, since greater concentrations of progesterone in the uterine environment during early stages of gestation was related with improved embryonic development (Lonergan 2011).

Thereby, two experiments were proposed to test the use of color Doppler ultrasonography to detect the success of AI of ET. The following hypotheses were tested: 1) Corpus luteum with greater vasculature at the time of ET results in greater pregnancy rates after ET; 2) Larger pre-ovulatory follicles presenting greater vascularity generates larger corpus luteum also presenting greater vascularity, resulting in a greater pregnancy rates after AI.

\section{MATERIALS AND METHODS}

Animals and ultrasound scanning. Nellore cows $(\mathrm{n}=198)$, Nellore primiparous $(n=80)$, Nellore heifers $(n=51)$, and Tabapuã cows $(n=21)$ were used during November to February in the Southern Hemisphere Tropical Zone. Animals were selected with no abnormalities in the reproductive tract, as determined by ultrasound examinations (Ginther 1998). Animals were kept under natural light and had free access to Brachiria brizantha pastures, traced-mineralized salt and water. Handling of animals was in accordance with the Institutional Animal Care and Use Committee (CEUA-FMVZ/USP, No.3030/2013).

A duplex pulsed-wave color-Doppler ultrasound instrument (MyLab30 Vet Gold; Esaote Healthcare, Genova, Italy) equipped with a multifrequency linear transducer for large animals transre- 
tal exams was used for the scanning. For the gray-scale mode, the brightness and contrast controls of the monitor and the gain controls of the scanner were standardized to constant settings (Gastal et al. 2006). For color Doppler mode, all scans were performed at a constant color-gain setting and a velocity setting of $5 \mathrm{~cm} / \mathrm{s}$ (Pugliesi et al. 2014). All scans were recorded by video clips for further analyses using specific software (MyLab Desk; Esaote Healthcare, Genova, Italy).

Image analyses. Video clips of the scanning were used to select still frames of the preovulatory follicles (POF) and corpus luteum (CL). The maximum diameter of POF and CL was determined using the software caliper function, and the mean of two perpendicular diameters were used for analyzes. The maximum CL area was determined using the software tracing function. For CL with cavity, the diameter and area of the cavity was subtracted from the total area (Kastelic et al. 1990). The percentage of POF wall and luteal tissue with vascular signals was determined subjectively by watching the color Doppler video clip, as previously described (Ginther et al. 2007).

Experiment 1. Nellore cows $(n=43)$ were submitted to the protocol of estrus synchronization as described in Figure 1. Seven days after ovulation, ultrasound scan was done searching for CL, and at the presence of CL the cow was submitted to embryo transfer. All scans were done by the same operator and a video clip re- corded in B-mode and color-Doppler mode for further analyzes of CL diameter, area, and vascularity.

The embryos were produced by in vitro fertilization, using oocytes from Brangus breed cows and semen from the same bull and all were graded as one for quality (International Embryo Transfer Society, IETS). The embryo transfer procedure was done by the same operator, and the embryo placed at the uterine horn ipsilateral of the ovary with CL. Gestational diagnosis was done thirty days after ovulation by ultrasound scanning. The experiment 1 design is shown in Figure 2.

Experiment 2. Heifers, primiparous and pluriparous Nellore cows and pluriparous Tabapuã cows (total of animals $=307$ ) were submitted to the same protocol of estrous synchronization for artificial insemination, as described in Figure 3. All animals were inseminated one day after ovulation using semen from the same bull. Ultrasound scans were done by the same operator at the time of insemination and eleven days after, to search for POF and CL, respectively. A video clip of the POF and CL scanning were recorded in B-mode and color-Doppler mode for further analyzes of POF diameter and vascularity; as well CL diameter, area and vascularity. The gestational diagnosis was done thirty days after ovulation by ultrasonography. Experiment 2 design is shown in Figure 4.

Statistical analyses. Comparisons of proportions were done by chi-square. Objective data normality was verified by Kolmogo-

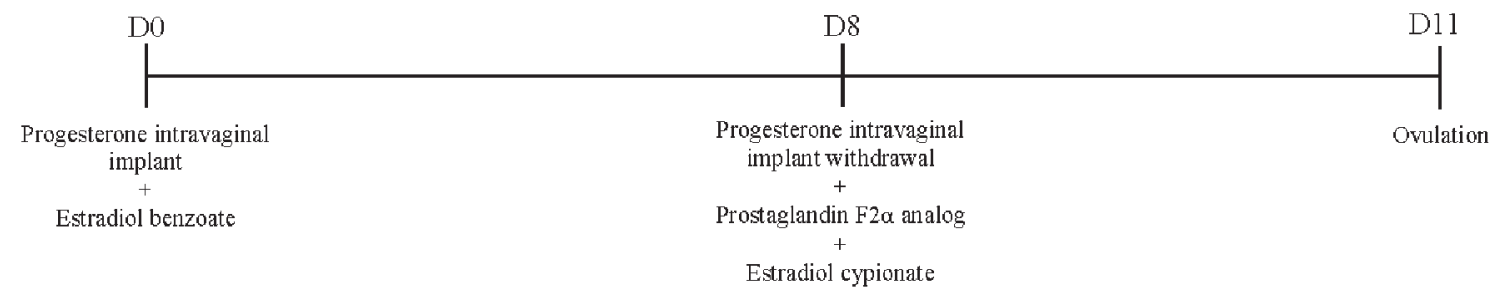

Fig.1. Protocol of estrous synchronization for fixed-timed embryo transfer (Experiment 1).

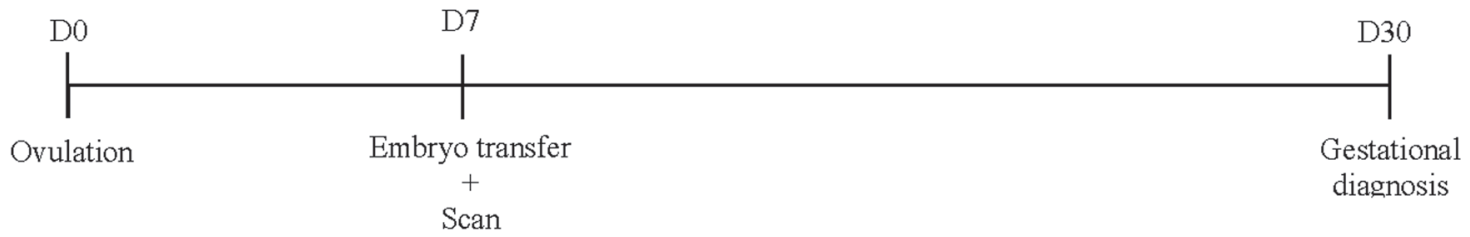

Fig.2. Experimental design (Experiment 1).

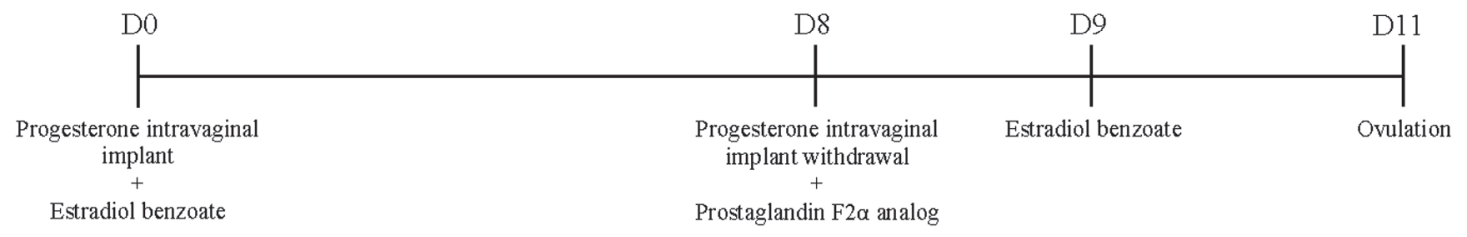

Fig.3. Protocol of estrous synchronization for fixed-time artificial insemination (Experiment 2)

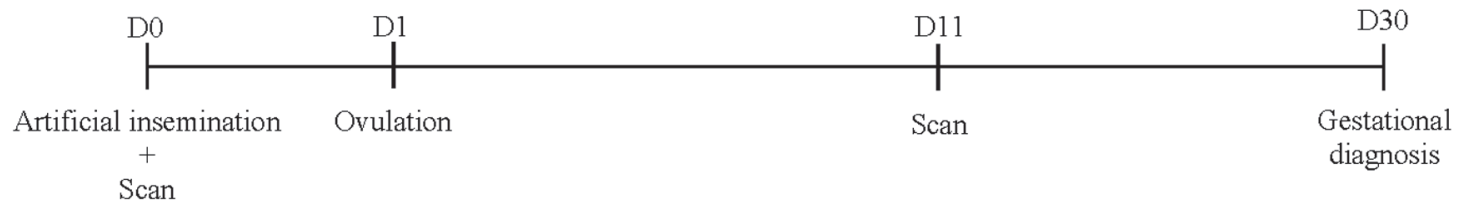

Fig.4. Experimental design (Experiment 2). 
rov-Smirnov test. Data not normally distributed were transformed in log of rank. Variance analyzes were done by SAS program (GLM procedure; version 9.2; SAS Institute Inc., Cary, NC) to determine principal effects and interaction. The student $t$-test was used to search differences between means in the same group or among groups if principal effects or interaction was significant. The probability between $P \leq 0.10$ and $P>0.05$ indicated approaching significance and $P \leq 0.05$ indicated significance.

\section{RESULTS}

\section{Experiment 1}

Cows were divided in two groups according to CL vascularity at the time of embryo transfer: $\mathrm{G} \leq 40(0-40 \%), \mathrm{G}>50$ (41-100\%). The means of CL diameter and pregnancy rate are shown in Table 1. A positive effect between CL vascularity and pregnancy rate was found, although no effect was found between CL size and pregnancy rate. In addition, the CL diameter was not correlated with vascularity.

\section{Experiment 2}

Animals were divided in five groups according to CL vascularity 11 days after AI: G 40 (0-40\%), G 50 (41-50\%), G 60 (51-60\%), G 70 (61-70\%), and G 100 (70-100\%). No difference was found between CL vascularity and pregnancy

Table 1. Mean of CL diameter and pregnancy rate in the groups divided by percentage of vascularity of the CL (Experiment 1). a and $b$ represents differences between treatments by chi-square test $(\mathrm{P}>0.05)$.

\begin{tabular}{lccc}
\hline $\begin{array}{l}\text { Groups (\% of CL } \\
\text { vascularity) }\end{array}$ & $\mathrm{N}$ & $\begin{array}{c}\text { CL diameter } \\
\text { (D7)(mm) }\end{array}$ & $\begin{array}{c}\text { Pregnancy } \\
\text { rate(\%) }\end{array}$ \\
\hline $\begin{array}{l}\text { Until } 40 \\
41-100\end{array}$ & 12 & 17.51 & $0.0(0 / 12)^{\mathrm{a}}$ \\
TOTAL & 31 & 17.03 & $48.4(15 / 31)^{\mathrm{b}}$ \\
& 43 & $17.15 \pm 0.22$ & $34.88(15 / 43)$
\end{tabular}

Table 2. Mean of CL diameter and pregnancy rate in the groups divided by percentage of vascularity of the CL (Experiment 2)

\begin{tabular}{lccc}
\hline $\begin{array}{l}\text { Groups (\% of } \\
\text { CL vascularity) }\end{array}$ & $\mathrm{N}$ & $\begin{array}{c}\text { CL diameter } \\
\text { (D7)(mm) }\end{array}$ & $\begin{array}{c}\text { Pregnancy } \\
\text { rate }(\%)\end{array}$ \\
\hline Until 40 & 83 & 17.07 & $47.0(39 / 83)^{\mathrm{a}}$ \\
$41-50$ & 108 & 17.24 & $57.4(62 / 108)^{\mathrm{a}}$ \\
$51-60$ & 62 & 17.52 & $54.8(34 / 62)^{\mathrm{a}}$ \\
$61-70$ & 25 & 17.09 & $56.0(13 / 25)^{\mathrm{a}}$ \\
Greater than 71 & 10 & 17.60 & $30.0(3 / 10)^{\mathrm{b}}$ \\
TOTAL & 288 & $17.3 \pm 0.11$ & $52.4 \%(151 / 288)$ \\
\hline
\end{tabular}

$\mathrm{P}<0.05$.

Table 3. POF diameter and vascularity; CL diameter, area, vascularity, and area of vascularity of the animals with positive $(n=155)$ and negative $(n=151)$ gestational diagnosis (GD)

\begin{tabular}{|c|c|c|c|c|c|c|}
\hline & $\begin{array}{c}\text { POF } \\
\text { diameter } \\
(\mathrm{mm})\end{array}$ & $\begin{array}{c}\text { POF } \\
\text { vascul- } \\
\text { arity(\%) }\end{array}$ & $\begin{array}{c}\text { CL } \\
\text { diameter } \\
(\mathrm{mm})\end{array}$ & $\begin{array}{c}\text { CL } \\
\text { area } \\
(\mathrm{cm} 2)\end{array}$ & $\begin{array}{c}\text { CL } \\
\text { vascu- } \\
\text { larity (\%) }\end{array}$ & $\begin{array}{l}\text { CL area of } \\
\text { vascularity } \\
(\mathrm{cm} 2)\end{array}$ \\
\hline$+\mathrm{GD}$ & $13,0 \pm 0,25$ & $29,4 \pm 2,1$ & $17,52 \pm 0,3$ & $2,86 \pm 0,1$ & $51,99 \pm 1,0$ & $1,49 \pm 0,0$ \\
\hline - GD & $12,7 \pm 0,31$ & $29,3 \pm 2,0$ & $17,17 \pm 0,3$ & $2,74 \pm 0,1$ & $51,46 \pm 1,2$ & $1,42 \pm 0,0$ \\
\hline P-value & 0,21 & 0,48 & 0,21 & 0,07 & 0,36 & 0,12 \\
\hline
\end{tabular}

rate, except for the group G 100 , in which pregnancy rate was lower. In addition, the CL diameter was not correlated with vascularity, as shown in Table 2 .

Data was arranged in ascending order for POF diameter, POF vascularity, CL diameter, CL area, CL vascularity, and CL area of vascularity. No effect was found between any of the parameters on pregnancy rate, although was found a tendency $(P=0.07)$ effect of CL area on pregnancy rate (Table 3).

For additional comparisons, data was divided in two groups of low values and high values from the median (Table 4). Thereby, POF diameter affected positively CL area, vascularity and area of vascularity. POF vascularity affected positively CL vascularity and area of vascularity. CL diameter affected positively CL area and vascularity. CL area affected positively POF diameter and vascularity, and CL diameter. CL vascularity affected positively POF diameter and vascularity, and CL area of vascularity. CL area of vascularity affected positively all parameters.

Data was also organized in quartiles, and two groups were formed based on the first and third quartile for each parameter (Table 5). POF diameter affected positively POF vascularity, CL area, CL vascularity, and CL area of vascularity. POF vascularity affected positively POF diameter, CL vascularity, and CL area of vascularity. CL diameter affected positively POF diameter, CL diameter, CL area, CL and vascularity. CL area affected positively POF diameter, CL diameter, and CL area of vascularity. CL vascularity affected positively POF diameter, POF vascularity, and CL area of vascularity. CL area of vascularity affected positively POF diameter, CL area, and CL area of vascularity.

\section{DISCUSSION}

Measurements of follicle and CL size and vascularity were done prior to artificial insemination and embryo transfer. Previous studies also assessed these parameters in cattle (Siddiqui et al. 2008.), horses (Silva et al. 2006), and humans (Coulam et al. 1999, Bhal et al. 2001, Borini et al. 2001), and encountered a positive correlation between FL vascularity and fertility. In the present study, CL vascularity was positive related with pregnancy rate at the time of embryo transfer, but no relationship with fertility was noted when follicle size and vascularity were measured at the time of AI.

A positive correlation with follicle size at the time of AI and pregnancy rate was previously described (Sá Filho et al. 2010a). Follicle and CL size were also positive related (Wecker et al. 2012), but no interference in fertility was noted. In the present study, no relationship between CL size with fertility was noted, similarly as observed by Nuñes et al. (2011), although disagreeing with findings from Baruselli et al. (2003), Baruselli et al. (2004) and Sá Filho et al. (2010a, 2010b, 2010c).

The hypothesis $1 \ldots$ that corpus luteum with greater vasculature at the time of ET results in greater pregnancy rates after ET .... was supported. In experiment 1, pregnancy rate was greater in cows with greater vascularity of the CL. This finding can be supported by Bollwein et al. (2002b) data, in which was noted greater CL vascula- 
Table 4. Data arranged in groups with greater and lower values from the median. Analyzed parameters: POF diameter and vascularity; CL diameter, vascularity, area, and area of vascularity

\begin{tabular}{|c|c|c|c|c|c|c|c|c|}
\hline & \multicolumn{2}{|c|}{ Median } & \multirow{2}{*}{$\begin{array}{c}\text { POF } \\
\text { diameter } \\
(\mathrm{mm})\end{array}$} & \multirow{2}{*}{$\begin{array}{c}\text { POF } \\
\text { vascularity } \\
(\%)\end{array}$} & \multirow{2}{*}{$\begin{array}{c}\text { CL } \\
\text { diameter } \\
(\mathrm{mm})\end{array}$} & \multirow{2}{*}{$\begin{array}{c}\text { CL } \\
\text { area } \\
(\mathrm{cm} 2) \\
2,8 \pm 0,1\end{array}$} & \multirow{2}{*}{$\begin{array}{c}\text { CL } \\
\text { vascularity } \\
(\%)\end{array}$} & \multirow{2}{*}{$\begin{array}{c}\text { CL area of } \\
\text { vascularity } \\
(\mathrm{cm} 2)\end{array}$} \\
\hline POF diameter & 12,6 & Lower & & & & & & \\
\hline$(\mathrm{mm})$ & & Greater & $14,7 \pm 0,2$ & $32,2 \pm 1,9$ & $17,8 \pm 0,4$ & $3,1 \pm 0,1^{\mathrm{a}}$ & $51,7 \pm 1,2^{\mathrm{b}}$ & $1,6 \pm 0,1^{\mathrm{c}}$ \\
\hline POF vascularity & 30,0 & Lower & $13,0 \pm 0,2$ & $12,2 \pm 0,7$ & $17,9 \pm 0,4$ & $3,0 \pm 0,1$ & $46,4 \pm 1,1$ & $1,4 \pm 0,1$ \\
\hline$(\%)$ & & Greater & $13,3 \pm 0,2$ & $44,5 \pm 1,4$ & $17,5 \pm 0,3$ & $2,9 \pm 0,1$ & $52,0 \pm 1,3^{\mathrm{d}}$ & $1,5 \pm 0,1^{\mathrm{e}}$ \\
\hline CL diameter & 18,1 & Lower & $13,0 \pm 0,2$ & $31,0 \pm 2,0$ & $15,0 \pm 0,2$ & $2,6 \pm 0,1$ & $49,3 \pm 1,2$ & $1,3 \pm 0,1$ \\
\hline (mm) & & Greater & $13,2 \pm 0,2$ & $29,2 \pm 2,1$ & $20,3 \pm 0,2$ & $3,2 \pm 0,1^{\mathrm{f}}$ & $49,4 \pm 1,2$ & $1,6 \pm 0,1^{g}$ \\
\hline CL area & 2,8 & Lower & $12,5 \pm 0,2$ & $29,0 \pm 1,9$ & $16,2 \pm 0,3$ & $2,4 \pm 0,1$ & $48,3 \pm 1,2$ & $1,2 \pm 0,1$ \\
\hline (cm2) & & Greater & $13,7 \pm 0,2^{\mathrm{h}}$ & $31,3 \pm 2,1$ & $19,1 \pm 0,3 \mathrm{i}$ & $3,5 \pm 0,1$ & $50,4 \pm 1,2$ & $1,7 \pm 0,1^{\mathrm{j}}$ \\
\hline CL vascularity & 50,0 & Lower & $12,5 \pm 0,2$ & $25,9 \pm 2,1$ & $17,7 \pm 0,4$ & $3,0 \pm 0,1$ & $38,9 \pm 0,6$ & $1,2 \pm 0,1$ \\
\hline$(\%)$ & & Greater & $13,6 \pm 0,2^{\mathrm{k}}$ & $33,6 \pm 1,9^{1}$ & $17,6 \pm 0,3$ & $2,9 \pm 0,1$ & $58,1 \pm 0,8$ & $1,7 \pm 0,1^{\mathrm{m}}$ \\
\hline CL area of & 1,4 & Lower & $12,3 \pm 0,2$ & $26,4 \pm 1,9$ & $16,6 \pm 0,3$ & $2,5 \pm 0,1$ & $42,3 \pm 0,9$ & $1,1 \pm 0,1$ \\
\hline vascularity $(\mathrm{cm} 2)$ & & Greater & $13,9 \pm 0,2^{\mathrm{n}}$ & $33,6 \pm 2,0^{\circ}$ & $18,7 \pm 0,3^{p}$ & $3,3 \pm 0,1^{q}$ & $56,4 \pm 1,1^{\mathrm{r}}$ & $1,8 \pm 0,1$ \\
\hline
\end{tabular}

Bold values represent the MEAN \pm SEM of the parameter used to divide the groups. Values with significant differences are highlighted in grey. Superscript low case letters represent the following $\mathrm{p}$ values: ${ }^{\mathrm{a}} p=0.0004,{ }^{\mathrm{b}} p=0.001$, $p<0.0001,{ }^{\mathrm{d}} p=0.0007,{ }^{\mathrm{e}} p=0.02,{ }^{\mathrm{f}} p<0.0001,{ }^{\mathrm{g}} p<0.0001,{ }^{\mathrm{h}} p=0.0001,{ }^{\mathrm{i}} p<0.0001,{ }^{\mathrm{i}} p<0.0001,{ }^{\mathrm{k}} p<0.0001,{ }^{1} p=0.003,{ }^{\mathrm{m}}$ $p<0.0001,{ }^{\mathrm{n}} p<0.0001,{ }^{\circ} p=0.006,{ }^{\mathrm{p}} p<0.0001,{ }^{\mathrm{q}} p<0.0001,{ }^{\mathrm{r}} p<0.0001$.

Table 5. Data divided groups composed by the first and third quartiles of the data. Analyzed parameters: POF diameter and vascularity; CL diameter, vascularity, area, and area of vascularity

\begin{tabular}{|c|c|c|c|c|c|c|c|}
\hline & Quartiles & $\begin{array}{c}\text { POF } \\
\text { diameter } \\
(\mathrm{mm})\end{array}$ & $\begin{array}{c}\text { POF } \\
\text { vascularity } \\
(\%)\end{array}$ & $\begin{array}{c}\text { CL } \\
\text { diameter } \\
(\mathrm{mm})\end{array}$ & $\begin{array}{c}\text { CL } \\
\text { area } \\
\text { (cm2) }\end{array}$ & $\begin{array}{c}\text { CL } \\
\text { vascularity } \\
(\%)\end{array}$ & $\begin{array}{c}\text { CL area of } \\
\text { vascularity } \\
(\mathrm{cm} 2)\end{array}$ \\
\hline POF diameter & 1st $(11,8)$ & $10,6 \pm 0,1$ & $27,8 \pm 2,8$ & $17,7 \pm 0,4$ & $2,6 \pm 0,1$ & $46,7 \pm 1,7$ & $1,2 \pm 0,1$ \\
\hline$(\mathrm{mm})$ & 3rd $(14,3)$ & $16,3 \pm 0,2$ & $34,1 \pm 2,5^{\mathrm{a}}$ & $18,1 \pm 0,5$ & $3,2 \pm 0,1^{\mathrm{b}}$ & $56,7 \pm 1,8^{\mathrm{c}}$ & $1,8 \pm 0,1^{\mathrm{d}}$ \\
\hline POF vascularity & 1st (10) & $12,7 \pm 0,3$ & $7,7 \pm 0,5$ & $17,8 \pm 0,5$ & $2,9 \pm 0,1$ & $46,4 \pm 1,2$ & $1,4 \pm 0,1$ \\
\hline$(\%)$ & $3 r d(40)$ & $13,6 \pm 0,3^{\mathrm{e}}$ & $51,9 \pm 1,6$ & $17,3 \pm 0,4$ & $2,9 \pm 0,1$ & $51,9 \pm 1,6^{\mathrm{f}}$ & $1,5 \pm 0,1^{\mathrm{g}}$ \\
\hline CL diameter & 1st $(15,6)$ & $12,1 \pm 0,3$ & $29,2 \pm 2,8$ & $15,3 \pm 0,3$ & $2,2 \pm 0,1$ & $49,8 \pm 1,7$ & $1,1 \pm 0,1$ \\
\hline$(\mathrm{mm})$ & 3rd $(20,0)$ & $13,8 \pm 0,3^{\mathrm{h}}$ & $31,4 \pm 2,8$ & $20,1 \pm 0,4$ & $3,8 \pm 0,1^{\mathrm{i}}$ & $49,1 \pm 1,5$ & $1,9 \pm 0,1^{j}$ \\
\hline CL area & 1st $(2,4)$ & $12,1 \pm 0,3$ & $29,2 \pm 2,8$ & $15,4 \pm 0,3$ & $2,2 \pm 0,1$ & $50,0 \pm 1,7$ & $1,1 \pm 0,1$ \\
\hline (cm2) & $3 r d(3,3)$ & $13,8 \pm 0,3^{\mathrm{k}}$ & $31,4 \pm 2,8$ & $20,1 \pm 0,4^{1}$ & $3,8 \pm 0,1$ & $49,1 \pm 1,5$ & $1,9 \pm 0,1^{\mathrm{m}}$ \\
\hline CL vascularity & 1st (40) & $12,4 \pm 0,2$ & $26,2 \pm 2,5$ & $17,4 \pm 0,4$ & $2,9 \pm 0,1$ & $36,4 \pm 0,6$ & $1,1 \pm 0,1$ \\
\hline (\%) & $3 r d(60)$ & $14,1 \pm 0,3^{\mathrm{n}}$ & $35,4 \pm 2,3^{\circ}$ & $17,4 \pm 0,4$ & $2,9 \pm 0,1$ & $64,4 \pm 0,8$ & $1,9 \pm 0,1^{\mathrm{p}}$ \\
\hline CL area of & 1st $(1,1)$ & $12,2 \pm 0,3$ & $30,2 \pm 2,9$ & $16,3 \pm 0,4$ & $2,4 \pm 0,1$ & $37,1 \pm 1,0$ & $0,9 \pm 0,1$ \\
\hline vascularity $(\mathrm{cm} 2)$ & 3rd $(1,8)$ & $14,5 \pm 0,3^{q}$ & $32,6 \pm 2,7$ & $19,8 \pm 0,4^{r}$ & $3,5 \pm 0,1^{s}$ & $60,4 \pm 1,5^{t}$ & $2,1 \pm 0,1$ \\
\hline
\end{tabular}

Bold values represent the MEAN \pm SEM of the parameter used to divide the groups. Values with significant differences are highlighted in grey. Superscript low case letters represent the following $\mathrm{p}$ values: ${ }^{\mathrm{a}} p=0.05,{ }^{\mathrm{b}} p<0.0001,{ }^{\mathrm{c}}$ $p<0.0001,{ }^{\mathrm{d}} p<0.0001,{ }^{\mathrm{e}} p=0.007,{ }^{\mathrm{f}} p=0.004,{ }^{\mathrm{g}} p=0.03,{ }^{\mathrm{h}} p<0.0001,{ }^{\mathrm{i}} p<0.0001,{ }^{\mathrm{j}} \mathrm{p}<0.0001,{ }^{\mathrm{k}} \mathrm{P}_{\mathrm{P}}<0.0001,{ }^{\mathrm{l}} p<0.0001,{ }^{\mathrm{m}}$ $p<0.0001,{ }^{\mathrm{n}} p<0.0001,{ }^{\circ} p=0.0004,{ }^{\mathrm{p}} p<0.0001,{ }^{\mathrm{q}} p<0.0001,{ }^{\mathrm{r}} p<0.0001,{ }^{\mathrm{s}} p<0.0001,{ }^{\mathrm{t}} \mathrm{V}<0.0001$.

rity associated with higher CL function. Previous studies indicated that CL vascularity may represent fertility and, since CL vascularity increases in parallel with systemic circulation of progesterone, it may be a useful method for pregnancy diagnosis (Acosta et al. 2003, Utt et al. 2009). In addition, higher CL function is also associated with greater progesterone concentration in the uterine environment, which is associated with improved embryo development (Lonergan 2011). The sum of these characteristics of CL vascularity supports that the positive correlation between CL vascularity and fertility may be due to increased systemic progesterone concentration. However, in the present study systemic progesterone was not measured, and further studies are necessary.

The hypothesis 2 that pre-ovulatory follicles larger and with greater vasculature generates larger and with greater vasculature corpus luteum, resulting in a greater pregnancy rates after AI was partially supported. In experiment 2 , greater follicular size and vascularity originated also greater
CL size and vascularity. This finding may be a result of the increased systemic estradiol, as shown previously (Reynolds et al. 2000, Bollwein et al. 2002a). Although a positive correlation among follicular size, follicular vascularity, CL size, and CL vascularity was observed, no benefit on fertility among each of these parameters was noted, and in contrast lower fertility rate was noted in cows with CL vascularity greater than $70 \%$. Hypothetically, the animals used in experiment 2 were maintained in over nutrition and were extremely selected for fertility, which could be the reason for no significant differences on pregnancy rate among all parameters analyzed. A herd with possible greater variability of reproductive status (different degrees of body scores or inseminated in two different climate seasons), should be used for further investigation, and test the applicability of the evaluation of follicle size and vascularity in practice. In addition, the lower fertility rate in cows with the greatest CL vascularity was an unexpected finding and with weak support owing to the low number of animal. However, pre- 
vious studies (Parr et al. 2012) showed a deleterious effect of higher concentration of progesterone in the embryo viability, and appeared to be a suitable hypothesis for the low fertility rate in these animals with higher CL vascularity, which indirectly showed higher CL function and, probably, a higher progesterone concentration in the blood.

In conclusion, in the present study fertility was positively related with CL vascularity prior to embryo transfer procedure, but no relationship between all parameters analyzed in follicle were associated with fertility prior to artificial insemination. The conflicting results after AI and ET is suggested to be a consequence from different herds conditions and needs to be tested. Therefore, further studies including more heterogeneous herds and hormone profiles are necessary to improve these findings.

\section{REFERENCES}

Acosta T.J., Hayashi K.G., Ohtani M. \& Miyamoto A. 2003. Local changes in blood flow within the preovulatory follicle wall and early corpus luteum in cows. Reproduction 125:759-767.

Acosta T.J. \& Miyamoto A. 2004. Vascular control of ovarian function: ovulation, corpus luteum formation and regression. Anim. Reprod. Sci. 8283:127-140.

Alvarez-Clau A. \& Liste R. 2005. Ultrasonographic characterization of the uterine artery in the nonestrus bitch. Ultrasound Med. Biol. 31:15831587.

Baruselli O.S., Marques M.O., Carvalho N.A.T., Berber R.C.A., Valentin R., Carvalho filho A.F. \& Costa Neto W.P. 2003. Dinâmica folicular e taxa de prenhez em novilhas receptoras de embrião (Bos taurus indicus x Bos taurus taurus) tratadas com o protocolo "Ovsynch" para inovulação em tempo fixo. Braz. J. Vet. Res. Anim. Sci. 40:96-106.

Baruselli P.S., Reis E.L., Marques M.O., Nasser L.F. \& Bó G.A. 2004. The use of hormonal treatments to improve reproductive performance of anestrous beef cattle in tropical climates. Anim. Reprod. Sci. 82/83:479-486.

Bhal P.S., Pugh N.D., Gregory L., O’Brien S. \& Shaw R.W. 2001. Perifollicular vascularity as a potential variable affecting outcome in stimulated intrauterine insemination treatment cycles: a study using transvaginal power Doppler. Hum. Reprod. 16:1682-1689.

Bisinotto R.S. \& Santos J.E.P. 2011. The use of endocrine treatments to improve pregnancy rates in cattle. Reprod. Fertil. Develop. 24:258-266.

Bisinotto R.S., Ibiapina B.T., Pontes E.O., Bertan C.M., Satrapa R., Barros C.M. \& Binelli M. 2012. Luteal function and follicular growth following follicular aspiration during the peri-luteolysis period in Bos indicus and crossbred cattle. Reprod. Domest. Anim. 47:319-327.

Blanco P.G., Rodríguez R., Rube A., Arias D.O., Tórtoba M., Díaz J.D. \& Gobello C. 2011. Doppler ultrasonographic assessment of maternal and fetal blood flow in abnormal canine pregnancy. Anim. Reprod. Sci. 126:130-135.

Bollwein H., Meyer H.H.D., Maierl J., Weber F., Baumgartner U. \& Stolla R. 2000. Transrectal Doppler sonography of uterine blood flow in cows during the estrous cicle. Theriogenology 53:1541-1552.

Bollwein H., Baumgartner U. \& Stolla R. 2002a. Transrectal Doppler sonography of uterine blood flow in cows during pregnancy. Theriogenology 57:2053-2061.

Bollwein H., Weber F., Kolberg B. \& Stolla R. 2002b. Uterine and ovarian blood flow during the estrous cycle in mares. Theriogenology 65:21292138.

Bollwein H., Weber F., Woschée I. \& Stolla R. 2004. Transrectal Doppler sonography of uterine and umbilical blood flow during pregnancy in mares. Theriogenology 61:499-509.

Borini A., Maccolini A., Tallarini A., Bonu M.A., Sciajno R. \& Flamigni C. 2001. Perifollicular vascularity and its relationship with oocyte maturity and IVF outcome. Ann. N.Y. Acad. Sci. 943:64-67.
Brito A.B., Miranda S.A., Ruas M.R., Santos R.R. \& Domingues S.F.S. 2010. Assessment of feline fetal viability by conceptus echobiometry and triplex Doppler ultrasonography of uterine and umbilical arteries. Anim. Reprod. Sci. 122:276-281.

Coulam C.B., Goodman C. \& Rinehart J.S. 1999. Colour Doppler indices of follicular blood flow as predictors of pregnancy after in-vitro fertilization and embryo transfer. Hum. Reprod. 14:1979-1982.

Di Salvo P., Bocci F., Zelli R. \& Polisca A. 2006. Doppler evaluation of maternal and fetal vessels during normal gestation in the bitch. Res. Vet. Sci. 81:382-388.

Gastal E.L., Gastal M.O. \& Ginther O.J. 2006. Relationships of changes in B-mode echotexture and colour-Doppler signals in the wall of the preovulatory follicle to changes in systemic oestradiol concentrations and the effects of human chorionic gonadotrophin in mares. Reproduction 131:699-709.

Geva E. \& Jaffe R.B. 2000. Role of vascular endothelial growth factor in ovarian physiology and pathology. Fertil. Steril. 74:429-438.

Ginther 0.J. 1998. Ultrasonic Imaging and Animal Reproduction: Book 3, Cattle. Equiservices Publishing, Cross Plains, WI.

Ginther O. J., Silva L.A., Araujo R.R. \& Beg M.A. 2007. Temporal associations among pulses of 13,14-dihydro-15-keto-PGF2alpha, luteal blood flow, and luteolysis in cattle. Biol. Reprod. 76:506-513.

Kastelic J.P., Pierson R.A. \& Ginther O.J. 1990. Ultrasonic morphology of corpora lutea and central luteal cavities during the estrous cycle and early pregnancy in heifers. Theriogenology 34:487-498.

Kastelic J.P. \& Thundathil J.C. 2008. Breeding soundness evaluation and semen analysis for predicting bull fertility. Reprod. Dom. Anim. 43:368373.

Köster K., Poulsen Nautrip C. \& Günzel-apel A.R. 2001. A Doppler ultrasonographic study of cyclic changes of ovarian perfusion in the Beagle bitch. Reproduction 122:453-461.

Lonergan P. 2011. Influence of progesterone on oocyte quality and embryo development in cows. Theriogenology 76:1594-1601.

Mann G.E. 2009. Corpus luteum size snd plasma progesterone concentration in cows. Anim. Reprod. Sci. 115:296-299.

Machado R., Bergamaschi M.A., Barbosa R.T., Oliveira C.A. \& Binelli M. 2008. Ovarian function in Nelore (Bos taurus indicus) cows after post-ovulation hormonal treatments. Theriogenology 69:798-804.

Miranda S.A. \& Domingues S.F.S. 2010. Conceptus ecobiometry and triplex Doppler ultrasonography of uterine and umbilical arteries for assessment of fetal viability in dog. Theriogenology 74:608-617.

Miyamoto A., Shirasuna K., Wijayagunawaedane M.P.B., Watanabe S., Hayashi M., Yamamoto D., Matsui M. \& Acosta T.J. 2005. Blood flow: a key regulatory component of corpus luteum function in the cow. Dom. Anim. Endocrinol. 29:329-339.

Miyamoto A., Shirasuna K., Hayashi K., Kamada D., Kawashima C., Kaneko E., Acosta T.J. \& Matsui M. 2006. A Potential Use of Color Ultrasound as a Tool for Reproductive Management: new observations using color ultrasound scanning that were not possible with imaging only in black and white. J. Reprod. Develop. 52:153-160.

Nautrup C.P. 1998. Doppler ultrasonography of canine maternal and fetal arteries during normal gestation. J. Reprod. Fertil. 112:301-314.

Nuñes R., De Castro T., Cutaia L. \& Bó G. 2011. Menchaca A. 2011. Pregnancy rates after administration of equine chorionic gonadotropin (eCG) at progesterone intravaginal device removal and 14 days after fi xed-time ai in beef cattle. Reprod. Fertil. Dev. 23:163.

Pareja O.S., Urbanetz A.A., Urbanetz L.A.M.L., Carvalho N.S. \& Piazza M.J. 2010. Características ecográficas do corpo lúteo em gestações iniciais: morfologia e vascularização. Revta Bras. Ginecol. Obstet. 32: 549-555.

Parr M.H., Mullen M.P., Crowe M.A., Roche J.F., Lonergan P., Evans A.C.O, Diskin M.G. 2012. Relationship between pregnancy per artificial insemination and early luteal concentrations of progesterone and establishment of repeatability estimates for these traits in Holstein-Friesian heifers. J. Dairy Sci. 95:2390-2396. 
Pereira B.S., Freire L.M.P., Pinto J.N., Domingues S.F.S. \& Silva L.D.M. 2012a. Triplex Doppler evaluation of uterine arteries in cyclic and pregnant domestic cats. Anim. Reprod. Sci. 130:99-104.

Pereira B.S., Pinto J.N., Freire L.M.P., Campello C.C., Domingues S.F.S. \& Silva L.D.M. 2012b. Study of the development of uteroplacental and fetal feline circulation by triplex Doppler. Theriogenology 77:989-997.

Polisca A., Scotti L., Orlandi R., Brecchia G. \& Boiti C. 2010. Doppler evaluation of maternal and fetal vessels during normal gestation in rabbits. Theriogenology 73:358-366.

Pugliesi G., Oliveira M.L., Scolari S.C., Lopes E., Pinaffi F.L.V., Miagawa B.T., Paiva Y.N., Maio J.R.G., Nogueira G.P. \& Binelli M. 2014. Corpus luteum development and function after supplementation of long-acting progesterone during the early luteal phase in beef cattle. Reprod. Dom. Anim. 49:85-91.

Reed K.L., Chaffin D.L. \& Anderson C.F. 1996. Umbilical venous doppler velocity pulsations and inferior vena cava pressure elevations in fetal lambs. Obstet. Gynecol. 8:617-620.

Reisinger K., Baal N., Mckinnon T., Münstedt K. \& Zygmunt M. 2007. The gonadotropins: tissue-specific angiogenic factors? Mol. Cell. Endocrinol. 269:65-80.

Reynolds L.P., Grazul-Bilska A.T. \& Redmer D.A. 2000. Angiogenesis in the corpus luteum. Endocrine 12:1-9.

Sá Filho M.F., Crespilho A.M., Santos J.E.P., Perry G.A. \& Baruselli P.S. 2010a. Ovarian follicle diameter at timed insemination and estrous response influence likelihood of ovulation and pregnancy after estrous synchronization with progesterone or progestin-based protocols in suckled Bos indicus cows. Anim. Reprod. Sci. 13:23-30.

Sá Filho M.F., Ayres H., Ferreira R.M., Marques M.O., Reis E.L., Silva R.C., Rodrigues C.A., Madureira E.H., Bó G.A. \& Baruselli P.S. 2010b. Equine chorionic gonadotropin and gonadotropin-releasing hormone enhance fertility in a norgestomet- based, timed artificial insemination protocol in suckled Nelore (Bos indicus) cows. Theriogenology 73:651-658.
Sá Filho M.F., Baldrighi J.M., Sales J.N., Crepaldi G.A., Carvalho J.B., Bó G.A. \& Baruselli P.S. 2011. Induction of ovarian follicular wave emergence and ovulation in progestin-based timed artificial insemination protocols for Bos indicus cattle. Anim. Reprod. Sci. 129:132-139.

Scotti L., Di Salvo P., Bocci F., Pieramati C. \& Polisca A. 2008. Doppler evaluation of maternal and fetal vessels during normal gestation in queen. Theriogenology 69:1111-1119.

Shrestha S.M., Costello M.F., Sjoblom P., Mcnally G., Bennett M., Steigrad S.J. \& Hughes G.J. 2006. Power Doppler ultrasound assessment of follicular vascularity in the early follicular phase and its relationship with outcome of in vitro fertilization. J. Assist. Reprod. Gen. 23:161-169.

Siddiqui M.A., Almamun M. \& Ginther O.J. 2008. Blood flow in the wall of the preovulatory follicle and its relationship to pregnancy establishment in heifers. Anim. Reprod. Sci. 113:287-292.

Silva L.A., Gastal E.L., Gastal M.O. \& Ginther O.J. 2006. Relationship between vascularity of the preovulatory follicle and establishment of pregnancy in mares. Anim. Reprod. 3:339-346.

Silva L.A. \& Ginther O.J. 2010. Local effect o the conceptus on uterine vascular perfusion during early pregnancy in heifers. Reproduction 139:453-463.

Siqueira L.G., Areas V.S., Ghetti A.M., Fonseca J.F., Palhao M.P., Fernandes C.A. \& Viana J.H. 2013. Color Doppler flow imaging for early detection of nonpregnant cattle at 20 days after timed artificial insemination. J. Dairy Sci. 96:6461-6472.

Utt M.D., Johnson G.L. \& Beal W.E. 2009. The evaluation of corpus luteum blood flow using color- flow Doppler ultrasound for early pregnancy diagnosis in bovine embryo recipients. Theriogenology 71:707-715.

Wecker F., Thedy D.X., Gonsioroski A.V. \& Borges J.B.S. 2012. Effect of administration of eCG or hCG 7 days after FTAI on the development of ovarian structures and pregnancy rates in beef cows. Acta Scient. Vet. 40:10721080. 